\title{
The Magic of Project Resolution in a Short Period of Time: Design Sprint Applied in Higher Education
}

\author{
Gastón Sanglier ${ }^{1}$, Carmen B. Martínez Cepa ${ }^{2}$, Inés Serrano Fernández ${ }^{2}$, Aurora Hernández González $z^{3}$ Juan \\ Carlos Zuíl Escobar ${ }^{2}$ \\ ${ }^{1}$ Escuela Politécnica Superior, San Pablo - CEU University, Madrid, España \\ ${ }^{2}$ Faculty of Medicine, San Pablo - CEU University, Madrid, España \\ ${ }^{3}$ Faculty of Pharmacy, San Pablo - CEU University, Madrid, España \\ Correspondence: Gastón Sanglier, Escuela Politécnica Superior, San Pablo - CEU University, España.
}

Received: February 23, 2021

Accepted: March 16, 2021

Online Published: March 18, 2021

doi:10.5539/mas.v15n2p45

URL: https://doi.org/10.5539/mas.v15n2p45

\begin{abstract}
The research conducted in this study was applied to multidisciplinary groups of Higher Education belonging to different degrees using the methodology proposed by the Design Sprint (DS) tool for the achievement of different challenges/objectives in a very short time. The methodology used is an adaptation of the one proposed by the DS, carried out in five non-consecutive stages/sessions focused on students of the first two years of different degrees of the CEU San Pablo University. The students, in general, have valued very positively the collaborative work in small groups, the time management and the administration of work under stress. The abandonment of the different challenges was set at 32\%. A high level of commitment has been appreciated among the students to reach the proposed challenges, however, the work of the mentors as guides, becomes essential in the first courses of the different degrees in a general way. The application of the SD methodology provides students with an increase in their performance, in their ability to work in teams and to adapt in the best possible way to the demands of a society that is increasingly demanding new technologies. Students have increased their ability to reflect, transform and innovate in the different objectives/challenges/projects demanded by the new circumstances and social strategies. The support of good mentors, critics and specialists in the different areas to be addressed is necessary to offer students a better learning experience.
\end{abstract}

Keywords: Design Sprint, teamwork, learning styles, leadership, educational outcomes, Higher Education, educational technology

\section{Introduction}

\subsection{Approach}

The European Higher Education Area has meant the incorporation of generic competencies to the learning objectives of the new degrees of Spanish universities, but the forms of communication have changed dizzyingly in the last decade, which has been helped by the health situation due to the pandemic we are experiencing, triggering the different forms of communication in basic tools for all agents of society. The scenario has changed greatly affecting also the academic and teaching scenario (Alaszewski, 2006; Morales 2020; Villafuerte et al., 2020; Feyen, 2020).

The pedagogical design for the formation and evaluation of teamwork competence must take into account the factors that influence and improve the effectiveness of teams (Long, 2020). We think of learning styles as cognitive, affective and physiological traits that serve as relatively stable indicators of how learners perceive interactions and respond to their learning environments, which is why studies are needed to determine how the introduction of different tools may affect these styles (Mullarkey \& Hevner, 2020).

\subsection{New Methodology}

The introduction of the Design Sprint methodology mostly used in the business environment can be a very valuable tool in the academic environment where team effort is increasingly rewarded with the new academic regulations (Knapp, Zeratsky, \& Kowitz, 2011). This new work tool makes students rethink their work in five stages: challenge definition stage, challenge understanding stage, sketching and decision stage, solution 
prototyping stage, and finally, the validation and presentation of the project/idea stage.

At CEU San Pablo University, this work tool has been introduced to address some challenges in different degrees being considered as a case of research within Higher Education. For this purpose, different experimental groups of teams of heterogeneous composition in terms of the preferred learning styles of its members have been generated. The facilitators/teachers have constituted a control group of randomly constituted teams, in order to contrast the influence of the Design Sprint tool and the different composition of the groups with the impact on academic performance and a possible incorporation in the way of working in some subjects. The convenience of forming teams whose members bring different personal characteristics has gone beyond the boundaries of organizations and entered the field of university education (Colas, González, \& De Pablos, 2013; Livari, 2015; Kim, Kwon, \& Cho, 2011; Maroto, 2007; Valerio \& Paredes, 2008).

\subsection{Agile Methodologies}

One could link the achievement or attainment of the challenge/challenge to the agile management of a Project as it focuses on teamwork and leadership, as well as working alone more focused on the development of the client's needs as the objectives of a hypothetical company (Altman, 2018). The use of methodologies, which could be called 'agile' are related methods of 'disciplined' or 'planned' work. In reality, this is what is applied to students enrolled in challenges through the Design Sprint methodology derived from Design Thinking (IBM).

Working with agile methodologies allows organizations, in this case the University, to improve the quality and efficiency of the students' work and ensure that the solutions provided in the different challenges can be useful to society (Keijzer-Broers \& Reuver, 2015; Jou, Hung, \& Lai, 2010; Schwaber, 2004; Sanglier et al., 2020). When a company applies this type of methodologies, the normal thing is to see/measure a growth due to a higher productivity, in this case and applied to the University, the productivity will be focused on a higher capacity in the students to face a series of problems and solve them in the best possible way.

The final results applying this type of agile project/challenge management is always a little less predictable, compared to older methods, but this should not necessarily be a disadvantage, since this way of working adapts to changes in a positive way, responding to the inconveniences that arise and solving them, the result is always more favorable than the results obtained by a team that is simply moving slowly towards the goal without considering a change of direction at a given time (Sy, 2007; Lledó, 2012; Fox, Sillito, \& Maurer, 2008; Emelyanova \& Voronina, 2014; Cohn, 2004; Da Silva, Martin, \& Maurer, 2011, da Silva, Silveira, \& Maurer, 2012).

This way of working incentivizes healthy and productive relationships between students who share responsibility for the outcome of the challenge and work together to achieve it.

Regular, and in this case tightly timed, meetings play a key role in successful teamwork and ensures that everyone is focused and working effectively by sharing ideas and solutions (Freire, 2009; Garrote, Jimenez, \& Serna, 2018).

The students in each group are organized around a mentor who does not make any decisions, only guides them and makes the group better. Management and decision making belongs only to the working group.

The mentor has only asked his assigned working group to be energetic and innovative in decision making and to bet on a winning solution to overcome the chosen challenge. He has ensured that the deadlines for delivery of the solution proposed by the working group are met and mediated possible problems that may arise in the group due to coexistence among the students.

Nowadays, students access information in a different way than a few years ago, they have gone from being consumers of information to being producers of it. Traditional methods are becoming less attractive and effective in engaging students in Higher Education towards more effective learning (Harnad, 1991; Pérez-Escoda, Castro, \& Fandos, 2016; Vera, Torres, \& Martínez, 2014).

The rapid advancement of technology means that students must possess 'extra skills' such as problem solving, persistence, critical thinking and collaborative work, in addition to those they are supposed to have to face the different subjects of the different degrees they choose to pursue (Preece, Sharp, \& Rogers, 2015; Salinas, 2002, 2004; Sein et al., 2011).

Students perceive the world as a place with large amounts of problems that they need to know how to address, and where they, themselves, see themselves as capable of participating. They expect some of that work to be done by their formal education at the university, but in reality, students need to learn to live and perform in increasingly competitive and globalized environments (Venable, 2006). Students should take advantage of their 
ability to investigate the problems that occur around them and be prepared to solve the challenges that life will confront them (Markus, Majchrzak, \& Gasser, 2002; Centeno \& Cubo, 2013; Sanglier et al., 2021; Arrieta \& Montes, 2011).

\subsection{Challenge-Based Learning}

Apart from agile methodologies that will undoubtedly help students to face their problems in a more effective way, Challenge-Based Learning (CBL) is being developed based on improved student learning through direct and active participation in open learning experiences (Fidalgo, Sein-Echaluce, \& García, 2017; Jou, Hung, \& Lai, 2010; Rekalde \& García, 2015). We believe that agile methodologies and ABRs can go hand in hand in helping to achieve those objectives identified above for improvement and effectiveness. One could say that it is experiential learning on the part of the student who is offered the opportunity to apply what has been learned in real situations.

ABR is a pedagogical approach incorporated in certain areas that demands a real-world perspective because it suggests that learning involves the student's doing/acting with respect to a topic of study/challenge/challenge (Jou, Hung, \& Lai, 2010). ABR takes advantage of students being engaged while developing key competencies such as multidisciplinary and collaborative work, developmental and effective communication, decision making, ethics, and leadership.

In general, it could be indicated that ABR in learning invites students to work with teachers, facilitators, mentors and experts in their communities, on real problems to develop a deeper understanding of the topics under study (Prieto, 2008; Barroso et al., 2012; Bonilla \& Aguaded, 2018). It is the challenge itself that leads to obtaining new knowledge and the necessary resources and tools; the approach confronts students with a relevant and open problem situation, for which a real situation is demanded; the product as a function of which students are demanded to create a solution that results in a concrete action; the process in which students analyze, design, develop and execute the solution they consider best to reach the final goal in a way that is testable and measurable, and finally the role of the teacher/facilitator in the importance of accompanying and advising students in the search for the solution (Poo-Delgado, 2013; Cabero, 2014; KeijzerBroers, De Reuver \& Guldemond, 2015).

\section{Method}

The forms of communication are changing by leaps and bounds in an increasingly demanding society, especially due to the latest health events that we are suffering, so that communication has become a basic tool for all agents of society. This has led to the emergence of new needs and challenges demanded by a new society increasingly oriented to new technologies.

At the CEU San Pablo University of Madrid, within the Values and Leadership Degree (TPVL), the possibility of applying the Design Sprint tool and methodology in the achievement of different challenges was publicized among the students of the first and second year of this degree. Students from different degrees and double degrees (Law, Medicine, Pharmacy, ADE, ADE+Marketing, etc.) were free to participate in the different challenges related to Communication and Sustainable Development.

Within the Communication topics, interesting challenges were established such as; communication with clients in the digital era, responsible communication and Big Data, commercial communication on the internet, communication in elderly groups, improving social networks from responsibility, business communication through storytelling, etc.

On the topic of Sustainable Development, issues have been proposed such as: expanding and improving social protection and assistance programs for the poorest and most vulnerable; ensuring health and well-being for everyone at all ages; achieving gender equality; ensuring access to affordable, reliable, sustainable and modern energy. Promote cohesive city-level strategies to drive innovation, boost sustainable economic and social development; strengthen adaptive capacity and resilience to natural disasters; integrate biodiversity and ecosystem values into local and national planning; promote peaceful societies, etc.

A pilot study was made on students, degrees and challenges assigned to four mentors for strategic and availability reasons, this meant having a sample of 118 students gathered around 3 Challenges (numbered as challenges 3,14 and 17) related to two fundamental aspects: Communication and Sustainable Development. The names assigned to these challenges were as follows:

- Challenge 3: Responsible Communication and Big Data - what should be the optimal responsible system for data storage, processing and analysis? 
- Challenge 14: Promote conservation and sustainable use of oceans, seas and marine resources for Sustainable Development.

- Challenge 17: Strengthen the means of implementation and revitalize global collaboration for sustainable development.

Challenge 3 attracted 28 participants, Challenge 14 attracted 78 participants and Challenge 17 attracted 12 participants. In the end there were 9 sprints or challenges carried out by the four mentors.

Once the challenge was selected by the students, the different groups were formed, trying not to have more than fifteen students per group. Each group was assigned a mentor, a guide responsible for setting the meetings to set the challenge, objectives, collaboration and discussion among the students and to ensure that they reached the end of the challenge.

All mentors worked to a similar schedule that was secretly revealed to the mentees at each meeting, five meetings and one per day. Due to the impossibility of working five days in a row as it is mandatory in the Design Sprint due to the students' commitments with their classes and exams, a maximum of fifteen days was set to carry out the five working sessions/meetings, in this way it was assured to work in a more or less continuous way, as recommended by the applied methodology.

The following scheme shows, in a very general way, how the process of participation in the different challenges was structured and its completion.

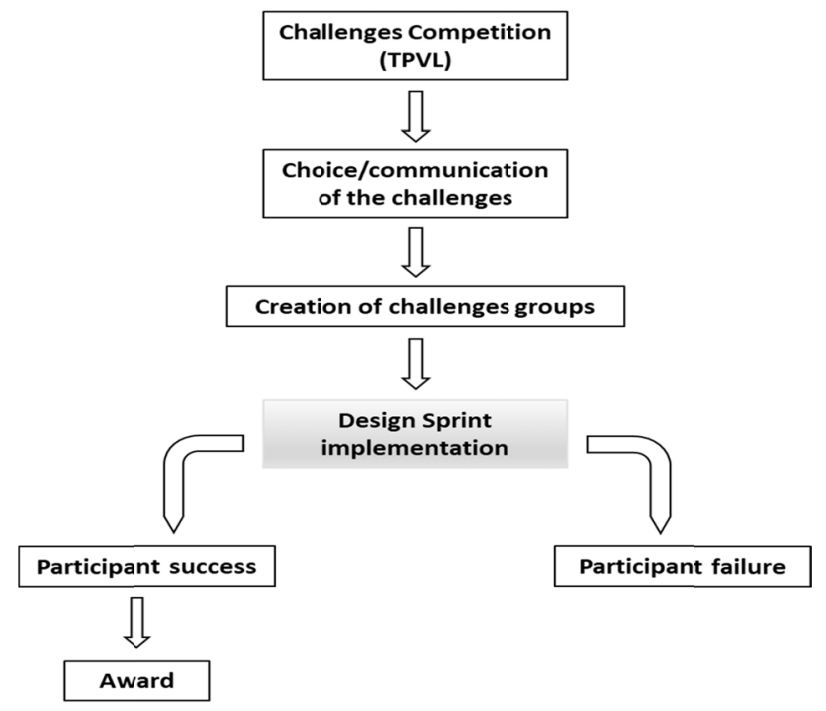

Figure 1. Stages applied in the study process

\subsection{Work Phases}

For the achievement of each challenge, different work phases were established, which were identical for all the groups, and which were discovered by the mentors on the same day of the session. The duration of the sessions was between one and two hours depending on the availability of the working group and the mentor. All sessions were conducted online between the participants and the mentor.

The following is a detailed description of the content that was developed by each group in the different work sessions.

DAY 1.- IDEATION

Challenges definition stage:

- Identify the challenge correctly: find out what it means, how far it has come, research stage.

- Establish deliverables and timeline, explaining to the student what the Design Sprint methodology consists of.

- Confirm the participation of the members of the channel/group.

- Explain the limitations of the method (speed of delivery, lack of knowledge of the team's skills, etc.). 


\section{DAY 2.- VALUE PROPOSITION}

Understanding the challenge.

- Share previous impressions: we have spent a few days looking for information about our challenge, what we think, what we have found, ...

- Setting the objective: this is the moment to choose ideas and discard others.

- Identify a series of key questions (yes/no) that we could ask our environment to check the validity of the objective.

- Understand the process: we are not the first ones to try to reach a solution to this challenge in this way: what do we bring as a novelty.

- And if we ask/search what the experts say.

- We define with all of the above the key opportunities.

- We empathize with the target audience: we understand the audience we are targeting (part of it, you can never reach everyone) and try to analyze if our solution is useful to them (empathy maps).

\section{DAY 3.- VALIDATION}

Stage of sketching and deciding.

- Search for relevant information about our key opportunities and target audience.

- Find inspiration with what competitors/other groups are doing: it is not about copying ideas, but does anyone know what other teams are doing, have we been interested in asking them, what do they tell us, does it resemble our idea, can we improve what they are doing?

- Share all the information we have at the moment.

- We vote on the most interesting idea.

- We design the storyboard of the experience we want to provide to our audience: we think.

\section{DAY 4.- PROTOTYPING}

Prototyping stage of the solution.

- Determine the prototype: use ppt, videos, mockups, drawings, role play, storyrelling,...

- Discuss options that best fit.

- Divide the work roles: who is going to be the builder, the scriptwriter, the producer, the interviewer...

- Start building the prototype and, if possible, test it with nearby agents.

- Give feedback on the information collected.

\section{DAY 5.- FINAL PRESENTATION}

Validation stage and presentation to the customer.

- Final presentation of the solution.

- Feedback (retrospective meeting).

- Share opinions on the Design Sprint performed.

- Celebrate the success of the group and wait for the jury's decision.

The final result of the work was a Powerpoint presentation of a maximum of 20 slides, and the creation of a five-minute video where the group had to expose the issue addressed and the proposed solution, highlighting the main stages they had to address to reach the solution.

All the material submitted by the different groups was subjected to an analysis by mentors and experts to choose the best challenge addressed and the best proposed solution under voting. The winning team was awarded a prize, as were the top students in the challenges.

As noted above, the Design Sprint methodology carried out with university students has a slight disadvantage compared to the one that could be applied to employees of a company, where the possibility of meeting for five consecutive days is possible. Despite the difficulties encountered in developing the sessions in the shortest possible time, difficulties also arose during some of the Sprint sessions, but all groups maintained a positive attitude and were always ready to get back on track by working as a team in an even more agile way. In addition, 
the following sentence from Knapp's book applies "It is important to emphasize that this decision-making process is not perfect... The sticky decision, if not perfect, is a good and quick exercise. That speed contributes greatly to the long-term goal of the sprint: getting real-world data into the Friday test" (Knapp, Zeratsky, \& Kowitz, 2016).

\section{Results}

The proposed research with the Design Sprint tool was carried out at CEU San Pablo University on three challenges with a total participation of 118 students from 16 degrees, of which 6 were double degrees.

The following table shows the different degrees, with the number of students who have participated in each of them, and the number of them who have achieved the challenge or have abandoned it.

Table 1. Titles participating in the various challenges with number of participants, dropouts and successes

\begin{tabular}{|c|c|c|c|c|c|c|c|c|c|c|}
\hline \multirow[b]{2}{*}{ DEGREES } & \multirow[b]{2}{*}{$\begin{array}{r}\text { Students } \\
\text { enrolled }\end{array}$} & \multirow{2}{*}{$\begin{array}{l}\text { Enrolled } \\
\text { Female } \\
\text { students }\end{array}$} & \multirow[b]{2}{*}{$\begin{array}{c}\text { Male } \\
\text { students }\end{array}$} & \multirow{2}{*}{$\begin{array}{l}\text { Dropouts } \\
\text { Female } \\
\text { students }\end{array}$} & \multirow[b]{2}{*}{$\begin{array}{c}\text { Male } \\
\text { students }\end{array}$} & \multicolumn{2}{|l|}{ Graduates } & \multicolumn{2}{|c|}{ Challenges } & \multirow[b]{2}{*}{17} \\
\hline & & & & & & $\begin{array}{l}\text { Female } \\
\text { students }\end{array}$ & $\begin{array}{c}\text { Male } \\
\text { students }\end{array}$ & 3 & 14 & \\
\hline BAM+Marketing & 11 & 6 & 5 & 1 & 2 & 5 & 3 & 0 & 11 & 0 \\
\hline $\begin{array}{l}\text { BAM+Business } \\
\text { Intelligent }\end{array}$ & 3 & 2 & 1 & 1 & 0 & 1 & 1 & 0 & 3 & 0 \\
\hline $\begin{array}{l}\text { Law+International } \\
\text { Relations }\end{array}$ & 2 & 2 & 0 & 0 & 0 & 2 & 0 & 0 & 2 & 0 \\
\hline Economics & 62 & 22 & 40 & 15 & 13 & 6 & 28 & 26 & 23 & 12 \\
\hline $\begin{array}{l}\text { Business Administration } \\
\text { and Management } \\
\text { (BAM) }\end{array}$ & 3 & 3 & 0 & 2 & 0 & 1 & 0 & 0 & 3 & 0 \\
\hline Biotechnology & 5 & 3 & 2 & 1 & 1 & 2 & 1 & 0 & 5 & 0 \\
\hline $\begin{array}{l}\text { Digital Comunication + } \\
\text { Marketing and Public } \\
\text { Relations }\end{array}$ & 6 & 6 & 0 & 1 & 0 & 5 & 0 & 0 & 6 & 0 \\
\hline History + Art History & 1 & 1 & 0 & 1 & 0 & 0 & 0 & 0 & 1 & 0 \\
\hline History & 1 & 0 & 1 & 0 & 1 & 0 & 0 & 0 & 1 & 0 \\
\hline Advertising & 1 & 0 & 1 & 0 & 0 & 0 & 1 & 0 & 1 & 0 \\
\hline Humanities & 8 & 6 & 2 & 5 & 1 & 1 & 1 & 0 & 8 & 0 \\
\hline Pharmacy & 8 & 7 & 1 & 7 & 1 & 0 & 0 & 1 & 8 & 0 \\
\hline Law & 1 & 1 & 0 & 1 & 0 & 0 & 0 & 0 & 1 & 0 \\
\hline Medicine & 1 & 1 & 0 & 1 & 0 & 0 & 0 & 1 & 0 & 0 \\
\hline Criminology & 4 & 3 & 1 & 0 & 0 & 3 & 1 & 0 & 4 & 0 \\
\hline $\begin{array}{l}\text { Economics + Business } \\
\text { Intelligence }\end{array}$ & 1 & 0 & 1 & 0 & 0 & 1 & 0 & 0 & 1 & 0 \\
\hline FINALTOTAL: & 118 & 63 & 55 & 36 & 19 & 27 & 36 & 28 & 78 & 12 \\
\hline
\end{tabular}

The table above shows that 63 female and 55 male students have enrolled, representing 53.39\% and $46.61 \%$ respectively, very similar participation data. As for the number of dropouts, i.e. students who did not achieve the challenge for different reasons, the number of female students was 36 and the number of male students 19 , representing $30.51 \%$ and $16.10 \%$ of students. In this case, the participating students were more constant in the pursuit of the chosen challenge. As for the achievement of the final challenge, the number of female students who succeeded was 27 and 36 male students, representing $22.88 \%$ and $30.51 \%$ respectively.

The challenges selected by the students were challenges 3, 14 and 17 of the challenges presented, for a total of 21 . The calculated participation percentages for each challenge were $23.72 \%, 66.10 \%$ and $10.18 \%$, respectively.

The following graph shows the varied participation of students in the different degrees. 


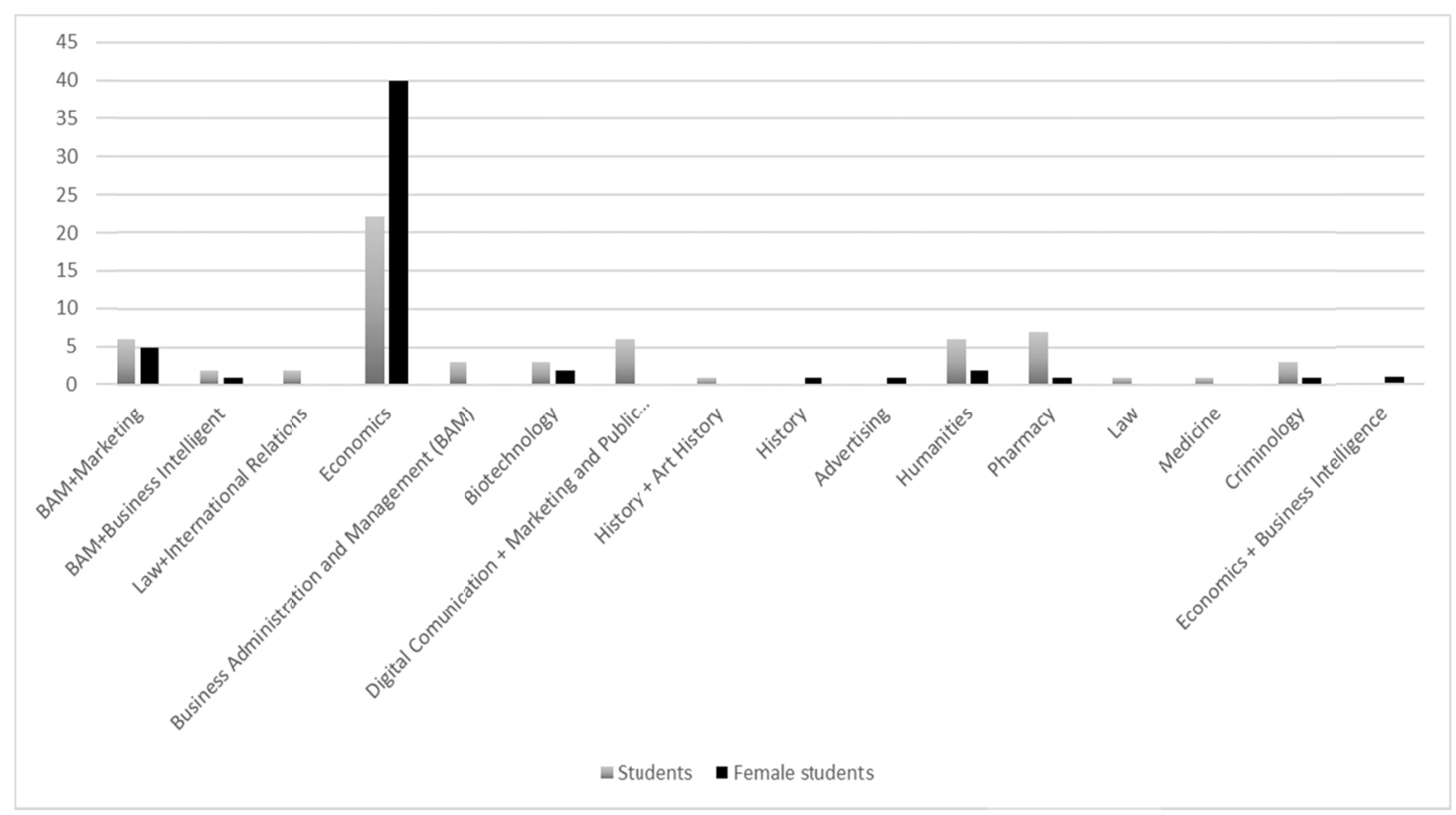

Figure 2. Student participation in the different degree programs

Figure 2 shows that the degree program with the highest number of students enrolled in the challenges was Economics, with a high percentage of participation. There are also degrees in which onlly female students have participated in the challenges, such as Medicine, Law, and the double degrees of History + History of Art and Law + International Relations. On the other hand, something similar happened with the students, only those belonging to the degrees of Advertising, History, and the double degree of Economics + Business Intelligence participated in the challenges. In the rest of the degrees, the participation has been distributed.

Figure 3 shows the number of students who have abandoned or achieved the different challenges proposed and chosen voluntarily by themselves.

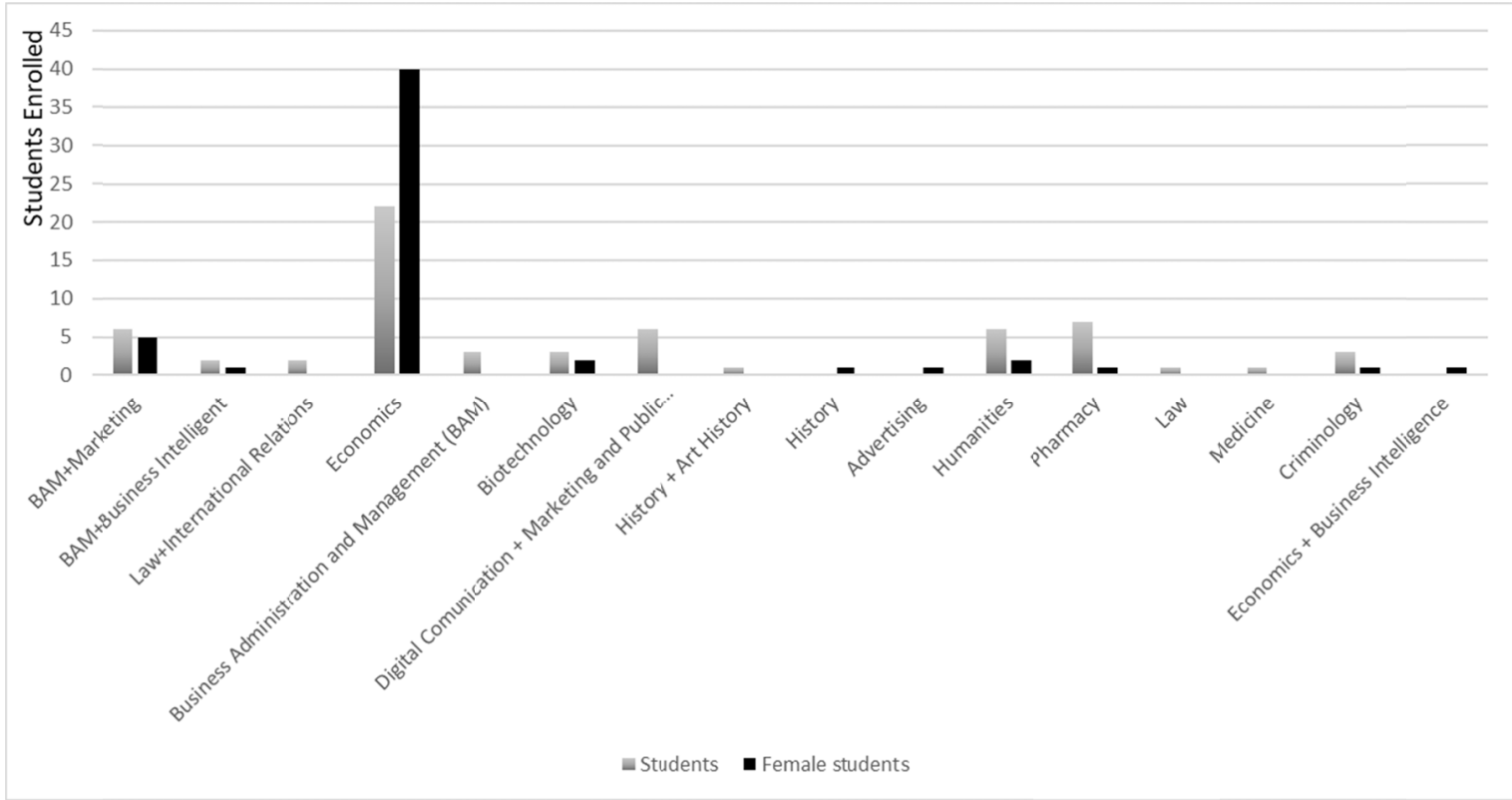

Figure 3. Dropouts and participation successes in the different degree programs

As the participation of both male and female students in the economics program has been very high, there is also a high percentage of students who have managed to meet the challenge satisfactorily; however, the success of female students here has been worse. There is also a high number of dropouts for both male and female students. Also noteworthy is the high number of dropouts by female students in the degrees of Pharmacy and Humanities. Female students are more successful in the double degrees of ADE + Marketing and Digital Communication + 
Advertising and International Relations.

The distribution of the challenges is very concentrated in the Economics degree as mentioned above and can be seen in Figure 4.

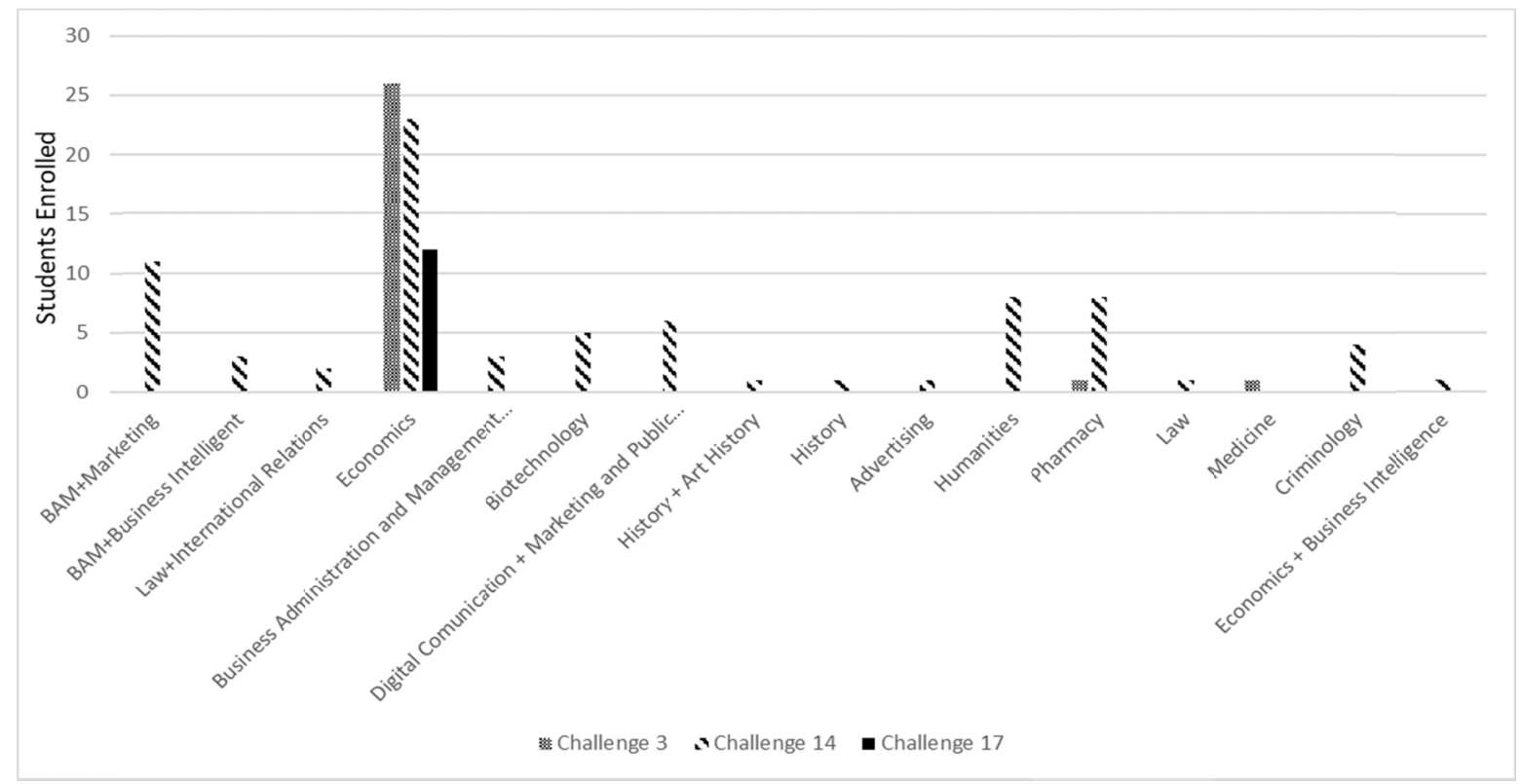

Figure 4. Distribution of the challenges in the different degrees

Challenge 14 is the most distributed among the different degrees. Challenge 3 has only been selected by students from the degrees of Economics, Pharmacy and Medicine. Challenge 17 was only selected by participants from the Economics degree program.

\subsection{Correlation Study}

To analyze the relationship that may exist between the different variables analyzed, a Pearson correlation study measuring the statistical linear relationship between two random continuous variables was performed using the StatGraphics Centurion computer software package (Baulina et al., 2018; Polhemus, 2006). The relationship is linear when a change in one variable is associated with a proportional change in another variable.

Correlation allows measuring the sign and magnitude of the trend between two variables. The sign indicates the direction of the relationship:

- a positive value indicates a direct or positive relationship,

- a negative value indicates an indirect, inverse or negative relationship,

- a null value indicates that there is no trend between the two variables (it may be that there is no relationship or that the relationship is more complex than a trend). In this case there is no linear correlation, but there may be another type.

On the other hand, the magnitude indicates the strength of the relationship, and takes values between -1 and 1 . The closer the value is to the extremes of the interval ( 1 or -1$)$ the stronger the trend of the variables, or the smaller the dispersion that exists at the points around the trend (Glass \& Stanley, 1974; Judd, McClelland, \& Ryan, 2009; Keppel, 1991).

Table 2 shows the summary statistics for each of the selected variables. It includes measures of central tendency, variability, and shape. The variables analyzed are: Enrolled (total number of male and female students enrolled in the challenge), ENR-Female Students (number of female students enrolled in the challenge), ENR-Students (number of male and female students enrolled in the challenge), DROP-Female Students (number of female students dropping out of the challenge), DROP-Students (number of male and female students dropping out of the challenge), GRA-Female Students (number of female students who manage to pass the challenge) GRA-Students (number of male and female students who manage to pass the challenge), Challenge-3 (male and female students enrolled in this challenge from different degrees), Challenge-14 (malle and female students enrolled in this challenge from different degrees) and Challenge-17 (male and female students enrolled in this challenge from different degrees). 
Table 2. Summary Pearson Correlation Statistics for the different variables

\begin{tabular}{|c|c|c|c|c|c|}
\hline & Enrolled & ENR-Female Students & ENR-Students & DROP-Female Students & DRP-Students \\
\hline Count & 16 & 16 & 16 & 16 & 16 \\
\hline Average & 7,375 & 3,9375 & 3,4375 & 2,25 & 1,1875 \\
\hline Median & 3,0 & 2,5 & 1,0 & 1,0 & 0 \\
\hline Mode & 1,0 & & & 1,0 & 0 \\
\hline Standard desviation & 14,8946 & 5,35996 & 9,83171 & 3,90726 & 3,20871 \\
\hline Coefficient of variance & $201,961 \%$ & $136,126 \%$ & $286,013 \%$ & $173,656 \%$ & $270,207 \%$ \\
\hline Mínimum & 1,0 & 0 & 0 & 0 & 0 \\
\hline Máximum & 62,0 & 22,0 & 40,0 & 15,0 & 13,0 \\
\hline Range & 61,0 & 22,0 & 40,0 & 15,0 & 13,0 \\
\hline Lower quartile & 1,0 & 1,0 & 0 & 0 & 0 \\
\hline Upper quartile & 7,0 & 6,0 & 1,5 & 1,5 & 1,0 \\
\hline Standarized range & 6,0 & 5,0 & 1,5 & 1,5 & 1,0 \\
\hline Standarized bias & 6,06628 & 4,5827 & 6,35534 & 4,44271 & 6,14638 \\
\hline Standarized Kurtosis & 11,7079 & 7,57312 & 12,5403 & 6,44399 & 11,9293 \\
\hline
\end{tabular}

GRA-Female Students GRA-Students Challenge-3 Challenge-14 Challenge-17

\begin{tabular}{lccccc}
\hline Count & 16 & 16 & 16 & 16 & 16 \\
Average & 1,6875 & 2,25 & 1,75 & 4,875 & 0,75 \\
Median & 1,0 & 0 & 0 & 3,0 & 0 \\
Mode & 0 & 0 & 0 & 1,0 & 0 \\
Standard desviation & 2,02382 & 6,91375 & 6,4756 & 5,7836 & 3,0 \\
Coefficient of variance & $119,93 \%$ & $307,278 \%$ & $370,034 \%$ & $118,638 \%$ & $400,0 \%$ \\
Mínimum & 0 & 0 & 0 & 0 & 0 \\
Máximum & 6,0 & 28,0 & 26,0 & 23,0 & 12,0 \\
Range & 6,0 & 28,0 & 26,0 & 23,0 & 12,0 \\
Lower quartile & 0 & 0 & 0 & 1,0 & 0 \\
Upper quartile & 2,5 & 1,0 & 0 & 7,0 & 0 \\
Standarized range & 2,5 & 1,0 & 0 & 6,0 & 0 \\
Standarized bias & 1,8775 & 6,38587 & 6,50172 & 3,73149 & 6,53197 \\
Standarized Kurtosis & 0,0714665 & 12,634 & 12,9763 & 5,06451 & 13,0639 \\
\hline
\end{tabular}

Of particular interest is the standardized skewness and standardized kurtosis, which can be used to determine whether the sample is from a normal distribution. Values of these statistics outside the range -2 to +2 indicate significant deviations from normality, which would tend to invalidate many of the statistical procedures usually applied to these data.

In this case, the following variables show standardized skewness and standardized kurtosis values outside the expected range: Enrolled, ENR-Female Students, ENR-Students, DROP-Female Students, DROP Students, GRA-Students, Challenge-3, Challenge-14, and Challenge-17. Only the variable GRA-Female Students shows values within the range of the skewness and standardized kurtosis.

The following variables show standardized kurtosis outside the expected range: Enrolled, ENR-Female Students, ENR-Students, DROP-Female Students, DROP-Students, GRA-Students, Challenge-3, Challenge-14 and Challenge-17. To make the variables more normal, transformations such as LOG(Y), ROOT(Y), or $1 / \mathrm{Y}$ can be performed.

Table 3 shows $95.0 \%$ confidence intervals for the means and standard deviations of each of the variables. These intervals bound the sampling error in the parameter estimates of the populations from which the data come. They can be used to help you judge how accurately the population means and standard deviations have been estimated. The intervals assume that the populations from which the samples are drawn can be represented by normal distributions. While confidence intervals for means are quite robust and not very sensitive to violations of this assumption, confidence intervals for standard deviations are very sensitive. The assumption of normality can be checked in the Analysis of a Variable procedure. 
Table $3.95 \%$ confidence intervals for the different variables

\begin{tabular}{lccccccc}
\hline & Media & Statistical error & Lower Limit & Upper Limit & Sigma & Lower Limit & Upper Limit \\
\hline Enrolled & 7,375 & 3,72366 & $-0,561805$ & 15,3118 & 14,8946 & 11,0027 & 23,0523 \\
ENR-Female Students & 3,9375 & 1,33999 & 1,08137 & 6,79363 & 5,35996 & 3,95943 & 8,29556 \\
ENR-Students & 3,4375 & 2,45793 & $-1,80146$ & 8,67646 & 9,83171 & 7,26273 & 15,2164 \\
DROP-Female Students & 2,25 & 0,976815 & 0,167965 & 4,33204 & 3,90726 & 2,88631 & 6,04723 \\
DROP-Students & 1,1875 & 0,802178 & $-0,522306$ & 2,89731 & 3,20871 & 2,37029 & 4,9661 \\
GRA-Female Students & 1,6875 & 0,505954 & 0,609082 & 2,76592 & 2,02382 & 1,495 & 3,13224 \\
GRA-Students & 2,25 & 1,72844 & $-1,43409$ & 5,93409 & 6,91375 & 5,10722 & 10,7004 \\
Challenge-3 & 1,75 & 1,6189 & $-1,70061$ & 5,20061 & 6,4756 & 4,78355 & 10,0222 \\
Challange-14 & 4,875 & 1,4459 & 1,79313 & 7,95687 & 5,7836 & 4,27237 & 8,95122 \\
Challange-17 & 0,75 & 0,75 & $-0,848591$ & 2,34859 & 3,0 & 2,21611 & 4,64307 \\
\hline
\end{tabular}

Table 4 shows the Pearson product moment correlations between each pair of variables. These correlation coefficients range from -1 to +1 (first number), and measure the strength of the linear relationship between the variables. Also shown in parentheses is the number of pairs of data used to calculate each coefficient (second number). The third number in each block of the table is a P-value that tests the statistical significance of the estimated correlations. P-values below 0.05 indicate correlations significantly different from zero, at a $95.0 \%$ confidence level. The following pairs of variables have P-values below 0.05: Enrolled and ENR-Female Students, Enrolled and ENR-Students, Enrolled and DROP-Female Students, Enrolled and DROP-Students, Enrolled and GRA-Female Students, Enrolled and GRA-Students, Enrolled and Challenge-3, Enrolled and Challenge-14, Enrolled and Challenge-17, ENR-Female Students and ENR-Students, ENR-Female Students and DROP-Female Students, ENR-Female Students and DROP-Students, ENR-Female Students and GRA-Female Students, ENR-Female Students and GRA-Students, ENR-Female Students and Challenge-3, ENR-Female Students and Challenge-14, ENR-Female Students and Challenge-17, ENR-Students and DROP-Female Students, ENR-Students and DROP-Students, ENR-Students and GRA-Female Students, ENR-Students and GRA-Students, ENR-Students and Challenge-3, ENR-Students and Challenge-14, ENR-Students and Challenge-17, DROP-Female Students and DRP-Students, DROP-Female Students and GRA-Students, DROP-Female Students and Challenge-3, and finally, DROP-Female Students and Challenge-14. 
Table 4. Correlations for the different pairs of variables

\begin{tabular}{|c|c|c|c|c|c|c|}
\hline & Enrolled & $\begin{array}{c}\text { ENR-Female } \\
\text { Students } \\
0,9640 \\
\end{array}$ & $\begin{array}{c}\text { ENR-Students } \\
0,9894 \\
\end{array}$ & $\begin{array}{c}\text { DROP-Female } \\
\text { Students } \\
0,9101 \\
\end{array}$ & $\begin{array}{c}\text { DROP-Students } \\
\mathbf{0 , 9 9 0 2} \\
\end{array}$ & $\begin{array}{c}\text { GRA-Female } \\
\text { Students } \\
0,6610 \\
\end{array}$ \\
\hline \multirow{2}{*}{ Enrolled } & & $(16)$ & $(16)$ & (16) & (16) & $(16)$ \\
\hline & & 0,0000 & 0,0000 & 0,0000 & 0,0000 & 0,0053 \\
\hline \multirow{3}{*}{$\begin{array}{l}\text { ENR-Female } \\
\text { Students }\end{array}$} & 0,9640 & & 0,9152 & 0,9335 & 0,9272 & 0,7110 \\
\hline & (16) & & (16) & (16) & (16) & (16) \\
\hline & 0,0000 & & 0,0000 & 0,0000 & 0,0000 & 0,0020 \\
\hline \multirow[t]{3}{*}{ ENR-Students } & 0,9894 & 0,9152 & & 0,8699 & 0,9947 & 0,6138 \\
\hline & $(16)$ & (16) & & $(16)$ & $(16)$ & (16) \\
\hline & 0,0000 & 0,0000 & & 0,0000 & 0,0000 & 0,0114 \\
\hline \multirow{3}{*}{$\begin{array}{l}\text { DROP-Female } \\
\text { Students }\end{array}$} & 0,9101 & 0,9335 & 0,8699 & & 0,8893 & 0,4152 \\
\hline & (16) & (16) & (16) & & (16) & (16) \\
\hline & 0,0000 & 0,0000 & 0,0000 & & 0,0000 & 0,1098 \\
\hline \multirow[t]{3}{*}{ DROP-Students } & 0,9902 & 0,9272 & 0,9947 & 0,8893 & & 0,6051 \\
\hline & $(16)$ & (16) & $(16)$ & $(16)$ & & (16) \\
\hline & 0,0000 & 0,0000 & 0,0000 & 0,0000 & & 0,0130 \\
\hline \multirow{3}{*}{$\begin{array}{l}\text { GRA-Female } \\
\text { Students }\end{array}$} & 0,6610 & 0,7110 & 0,6138 & 0,4152 & 0,6051 & \\
\hline & (16) & (16) & (16) & (16) & (16) & \\
\hline & 0,0053 & 0,0020 & 0,0114 & 0,1098 & 0,0130 & \\
\hline \multirow[t]{3}{*}{ GRA-Students } & 0,9869 & 0,9107 & 0,9987 & 0,8613 & 0,9894 & 0,6158 \\
\hline & $(16)$ & $(16)$ & $(16)$ & $(16)$ & $(16)$ & $(16)$ \\
\hline & 0,0000 & 0,0000 & 0,0000 & 0,0000 & 0,0000 & 0,0111 \\
\hline \multirow[t]{3}{*}{ Challenge-3 } & 0,9777 & 0,9023 & 0,9893 & 0,8827 & 0,9810 & 0,5532 \\
\hline & $(16)$ & $(16)$ & $(16)$ & $(16)$ & $(16)$ & $(16)$ \\
\hline & 0,0000 & 0,0000 & 0,0000 & 0,0000 & 0,0000 & 0,0262 \\
\hline \multirow[t]{3}{*}{ Challenge-14 } & 0,9316 & 0,9739 & 0,8803 & 0,8806 & 0,8994 & 0,7540 \\
\hline & $(16)$ & $(16)$ & $(16)$ & $(16)$ & $(16)$ & $(16)$ \\
\hline & 0,0000 & 0,0000 & 0,0000 & 0,0000 & 0,0000 & 0,0007 \\
\hline \multirow[t]{3}{*}{ Challenge-17 } & 0,9780 & 0,8986 & 0,9917 & 0,8702 & 0,9817 & 0,5682 \\
\hline & $(16)$ & (16) & $(16)$ & $(16)$ & (16) & (16) \\
\hline & 0,0000 & 0,0000 & 0,0000 & 0,0000 & 0,0000 & 0,0216 \\
\hline
\end{tabular}

\begin{tabular}{|c|c|c|c|c|}
\hline & $\begin{array}{c}\text { GRA-Female } \\
\text { Students }\end{array}$ & Challenge-3 & Challenge-14 & Challenge-17 \\
\hline \multirow{3}{*}{ Enrolled } & 0,9869 & 0,9777 & 0,9316 & 0,9780 \\
\hline & (16) & (16) & (16) & (16) \\
\hline & 0,0000 & 0,0000 & 0,0000 & 0,0000 \\
\hline \multirow{3}{*}{$\begin{array}{l}\text { ENR-Female } \\
\text { Students }\end{array}$} & 0,9107 & 0,9023 & 0,9739 & 0,8986 \\
\hline & (16) & (16) & (16) & (16) \\
\hline & 0,0000 & 0,0000 & 0,0000 & 0,0000 \\
\hline \multirow[t]{2}{*}{ ENR-Students } & $\begin{array}{l}\mathbf{0 , 9 9 8 7} \\
(16)\end{array}$ & $\begin{array}{l}\mathbf{0 , 9 8 9 3} \\
(16)\end{array}$ & $\begin{array}{l}0,8803 \\
(16)\end{array}$ & $\begin{array}{l}0,9917 \\
(16)\end{array}$ \\
\hline & 0,0000 & 0,0000 & 0,0000 & 0,0000 \\
\hline \multirow{3}{*}{$\begin{array}{l}\text { DROP-Female } \\
\text { Students }\end{array}$} & 0,8613 & 0,8827 & 0,8806 & 0,8702 \\
\hline & (16) & (16) & (16) & (16) \\
\hline & 0,0000 & 0,0000 & 0,0000 & 0,0000 \\
\hline \multirow{3}{*}{ DROP-Student } & 0,9894 & $\mathbf{0 , 9 8 1 0}$ & 0,8994 & $\mathbf{0 , 9 8 1 7}$ \\
\hline & (16) & (16) & (16) & (16) \\
\hline & 0,0000 & 0,0000 & 0,0000 & 0,0000 \\
\hline \multirow{3}{*}{$\begin{array}{l}\text { GRA-Female } \\
\text { Students }\end{array}$} & 0,6158 & 0,5532 & 0,7540 & 0,5682 \\
\hline & (16) & (16) & (16) & (16) \\
\hline & 0,0111 & 0,0262 & 0,0007 & 0,0216 \\
\hline \multirow[t]{2}{*}{ GRA-Students } & & $\begin{array}{l}\mathbf{0 , 9 9 0 2} \\
(16)\end{array}$ & $\begin{array}{l}0,8711 \\
(16)\end{array}$ & $\begin{array}{l}\mathbf{0 , 9 9 3 2} \\
(16)\end{array}$ \\
\hline & & 0,0000 & 0,0000 & 0,0000 \\
\hline \multirow[t]{2}{*}{ Challenge-3 } & $\begin{array}{l}\mathbf{0 , 9 9 0 2} \\
(16)\end{array}$ & & $\begin{array}{l}0,8357 \\
(16)\end{array}$ & $\begin{array}{l}\mathbf{0 , 9 9 8 6} \\
(16)\end{array}$ \\
\hline & 0,0000 & & 0,0001 & 0,0000 \\
\hline \multirow[t]{3}{*}{ Challenge-14 } & 0,8711 & 0,8357 & & 0,8357 \\
\hline & (16) & (16) & & (16) \\
\hline & 0,0000 & 0,0001 & & 0,0001 \\
\hline \multirow[t]{3}{*}{ Challenge-17 } & $\mathbf{0 , 9 9 3 2}$ & 0,9986 & 0,8357 & \\
\hline & (16) & (16) & (16) & \\
\hline & 0,0000 & 0,0000 & 0,0001 & \\
\hline
\end{tabular}


Pairs of variables with a high correlation are marked in bold, and those with a very low correlation are shown in green.

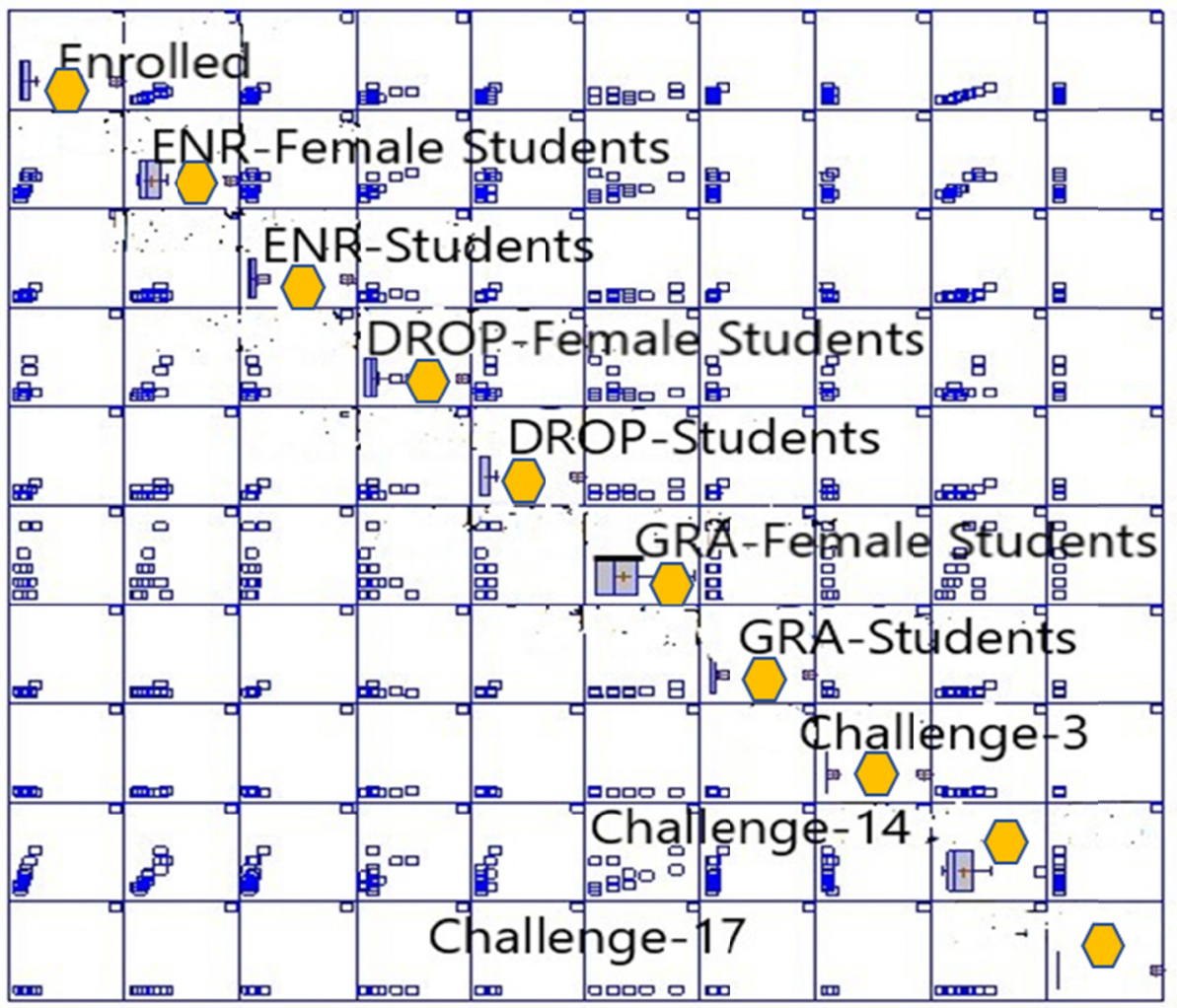

Figure 5. Distribución de correlaciones entre las diferentes variable:s

El gráfico 5 muestra de una forma más clara las relaciones que se presentan entre las variables analizadas en el estudio.

\subsection{Principal Component Analysis}

A principal components study has been carried out for the reduction of analysis data. The objective of applying this methodology is to transform a set of variables, called originals, into a new set of variables called principal components. As a measure of the amount of information incorporated in a component, its variance is used; the greater the variance, the greater the amount of information contained in the component. Therefore, the component with the highest variance is selected as the first component, and the one with the lowest variance is selected as the last component.

Table 5. Análisis de componentes principales

\begin{tabular}{llll}
\hline $\begin{array}{l}\text { Component } \\
\text { Number }\end{array}$ & Eigenvalor & $\begin{array}{l}\text { Percentage of } \\
\text { Variance }\end{array}$ & $\begin{array}{l}\text { Cumulative } \\
\text { Percentage }\end{array}$ \\
\hline 1 & 8,91373 & 89,137 & 89,137 \\
2 & 0,711738 & 7,117 & 96,255 \\
3 & 0,32024 & 3,202 & 99,457 \\
4 & 0,0454586 & 0,455 & 99,912 \\
5 & 0,00629237 & 0,063 & 99,975 \\
6 & 0,00158439 & 0,016 & 99,990 \\
7 & 0,000818909 & 0,008 & 99,999 \\
8 & 0,000141174 & 0,001 & 100,000 \\
9 & 0,0 & 0,000 & 100,000 \\
10 & 0,0 & 0,000 & 100,000 \\
\hline
\end{tabular}


The purpose of the analysis is to obtain a reduced number of linear combinations of the 10 variables (Enrolled, ENR-Female Students, ENR-Students, DROP-Female Students, DROP-Students, GRA-Female Students, GRA-Students, Challenge-3, Challenge-14 and Challenge-17) that explain the greatest variability in the data. In this case, only one component has been extracted, since it is the only one with an eigenvalue greater than or equal to 1.0 . This component explains $89.137 \%$ of the variability in the original data.

It is observed that for the first principal component there is a percentage of variance and accumulated variance of 89.137 , a very high percentage of information, which means that one principal component would be sufficient to express the other variables involved. This can also be seen in the sedimentation plot below, where only one component appears above the red selection line.

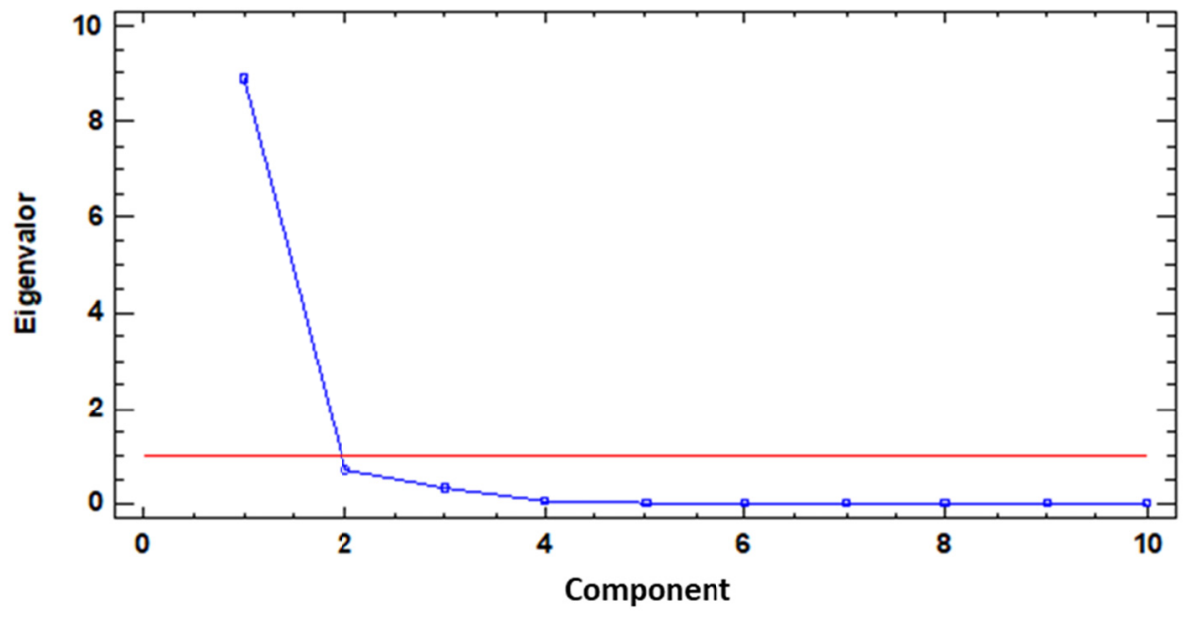

Figure 6. Principal component sedimentation plot

Its equation will be determined through the table of weights of the different components determined below using the same software as the one used in the calculation of the correlations.

Table 6. Table of weights of the principal components

\begin{tabular}{lcccccc}
\hline & Component & Component & Component & Component & Component & Component \\
& $\mathbf{1}$ & $\mathbf{2}$ & $\mathbf{3}$ & $\mathbf{4}$ & $\mathbf{5}$ & $\mathbf{6}$ \\
\hline Enrolled & 0,334833 & $-0,0227669$ & 0,0245352 & 0,0334876 & 0,0756497 & 0,00478809 \\
ENR-Female Students & 0,324787 & 0,121782 & $-0,368385$ & $-0,330229$ & $-0,0566067$ & 0,677576 \\
ENR-Students & 0,330193 & $-0,100883$ & 0,238002 & 0,230764 & 0,145466 & $-0,362141$ \\
DROP-Female Students & 0,305167 & $-0,274119$ & $-0,590769$ & $-0,30587$ & $-0,0355518$ & $-0,487004$ \\
DROP-Students & 0,330769 & $-0,104268$ & 0,132574 & 0,412039 & $-0,761049$ & 0,142061 \\
GRA-Female Students & 0,225829 & 0,864633 & 0,179994 & $-0,247884$ & $-0,0940252$ & $-0,248077$ \\
GRA-Students & 0,329266 & $-0,0988383$ & 0,27251 & 0,126336 & 0,563798 & 0,292229 \\
Challenge-3 & 0,326041 & $-0,196763$ & 0,248586 & $-0,31751$ & $-0,11407$ & $-0,0352118$ \\
Challenge-14 & 0,314297 & 0,248412 & $-0,434074$ & 0,571957 & 0,22038 & $-0,0403875$ \\
Challenge-17 & 0,326096 & $-0,175151$ & 0,289116 & $-0,260552$ & 0,0341135 & $-0,0505679$ \\
\hline
\end{tabular}




\begin{tabular}{lcccc}
\hline & Component & Component & Component & Component \\
& $\mathbf{7}$ & $\mathbf{8}$ & $\mathbf{9}$ & $\mathbf{1 0}$ \\
\hline Enrolled & 0,0000832006 & $-0,23961$ & 0,781144 & $-0,460761$ \\
ENR-Female Students & 0,0403318 & $-0,117585$ & $-0,298537$ & $-0,260832$ \\
ENR-Students & $-0,0218617$ & $-0,298895$ & $-0,547604$ & $-0,478441$ \\
DROP-Female Students & 0,0414025 & $-0,228316$ & 0,0127104 & 0,311009 \\
DROP-Students & 0,0691129 & $-0,151237$ & 0,010438 & 0,255406 \\
GRA-Female Students & 0,00305406 & $-0,105744$ & 0,00658354 & 0,161091 \\
GRA-Students & $-0,0561888$ & $-0,286029$ & 0,0224907 & 0,550319 \\
Challenge-3 & $-0,709257$ & 0,418422 & $2,02861 \mathrm{E}-13$ & $6,65663 \mathrm{E}-13$ \\
Challenge-14 & $-0,0593822$ & 0,519836 & $1,34042 \mathrm{E}-12$ & $7,16715 \mathrm{E}-13$ \\
Challenge-17 & 0,694022 & 0,475521 & $-1,59442 \mathrm{E}-13$ & $5,0385 \mathrm{E}-13$ \\
\hline
\end{tabular}

This table shows the equations of the principal components. For example, the first principal component equation is:

$\mathrm{C} 1=0.334833^{*}$ Enrolled $+0.324787 *$ ENR-Feamale $\quad$ Students $\quad+\quad 0.330193 *$ ENR-Students + $0.305167 *$ DROP-Female Students $+0.330769 *$ DROP-Students $+0.225829 *$ GRA-Female Students + $0.329266 *$ GRA-Students $+0.326041 *$ Challenge- $3+0.314297 *$ Challenge- $14+0.326096 *$ Challenge- 17 .

Where the values of the variables in the equation have been standardized by subtracting their means and dividing by their standard deviations.

In the same way as for $\mathrm{C} 1$, the other nine equations for each of the other principal components could be obtained by simply multiplying the variable by its corresponding weight. These equations would not be representative since they have eigenvalues below 1 .

\section{Discussion}

The number of female students participating was slightly higher than that of male students, $53.31 \%$ versus $46.61 \%$ respectively. However, the number of female students who dropped out of the challenge (30.51\%) was higher than that of male students $(16.10 \%)$. As for the achievement of the objective, i.e., the participants' success, the number of male students $(30.51 \%)$ was higher than that of female students $(22.88 \%)$. A high dropout rate of participants was observed, mainly due to a greater teaching load in the participants as the course progressed, which prevented them from facing their commitment to the challenge chosen in advance. There were also problems of commitment in setting up meetings, as it was difficult to schedule a timetable that suited everyone. The students who were unable to attend at the beginning were the first to become disconnected from the challenge. The fact of having to make the sessions very continuous has meant an important setback at the time of the commitments on the part of the students.

The degree with more students enrolled in the selected challenges was Economics, with a high percentage of participation much higher than the rest of the degrees. There are also degrees in which only female students have participated in the challenges, such as Medicine, Law, and the double degrees of History + History of Art and Law + International Relations. On the other hand, something similar happened with the students, only those belonging to the degrees of Advertising, History, and the double degree of Economics + Business Intelligence participated in the challenges. In the rest of the degrees, the participation has been very distributed. It should be noted that the success of female students has been mostly in the degrees of Economics, ADE + Marketing and Digital Communication + Advertising and Public Relations, as well as the large number of dropouts by female students in the degrees of Pharmacy and Humanities. There is little participation of students from Science degrees.

Challenge 14 is the most distributed among the different degrees, with $23.72 \%$ of participants. Challenge 3 was only selected by students from the degrees of Economics, Pharmacy and Medicine, with $66.10 \%$ of participants. Challenge 17 was only selected by participants from the Economics degree program, with $10.18 \%$ of participants.

The figure of the mentor, throughout the process of applying the methodology proposed by the Design Sprint during the development of the challenges, has been fundamental for its ability to supervise activities, guide the 
work teams, review the progress of the teams, channel the efforts, provide feedback on the proposals of the participating students and be like a guide through triggering questions but without giving answers or solutions. Giving up control of the group in order to guide the students in the process of learning and solving the challenge has been a challenge for the different mentors.

As all sessions are conducted online, the mentor loses the ability to see how the students interact and get to know them in a more efficient way. It diminishes their ability to review and guide in a significant way. It is desirable to carry out this type of learning experience in person.

Statistical studies of Pearson correlation and principal component analysis have been carried out in order to observe the relationships and simplifications between the different quantitative variables. The correlation study shows a good correlation between the ten qualitative variables analyzed, presenting cases of worse correlation between 0.4152 and 0.5682 for the following pairs of variables: DROP-Female Students and GRA-Female Students, Challenge-3 and GRA-Female Students, Challenge-17 and GRA-Female Students.

The principal component analysis of the ten variables shows that only one component can express $89.137 \%$ of the variability of the data, as can be seen in the sedimentation graph (graph 6) and in the principal component analysis table (table 5).

The application of the Design Sprint methodology has ensured that participating students will gain a deeper understanding of the issues/challenges, learn to diagnose and find various solutions to the challenge. Students are involved in the challenge and in the final solution to solve it. They will also be sensitized to the situations analyzed, develop research processes and carry them out through collaborative and multidisciplinary work involving students from different degrees. A greater approach of students to the real problems of the world, of their country or their community, that they establish relationships with people, teachers and experts, with specialized people that make them understand the problem and that form them as better professionals to face a somewhat uncertain future. Students strengthen the connection between university learning and the real environment. Also students can improve and develop communication skills through the use of social tools and media production techniques.

This type of challenge-based learning (CBL), use of agile methodologies and carried out with the Design Sprint is identified to evidence the link between learning and real problems of the environment, even if these are identified as challenges. These challenges demand skills that transcend what is taught in a University or Higher Education center. The information of the proposed methodology should be presented in a clear and gradual way to the students so that they can deepen their learning and avoid distractions due to an excessive amount of information. The different theories and events that may explain the phenomenon under study could be downplayed, focusing the student only on the results of the phenomenon under study. This type of study shows satisfactory results in terms of performance, satisfaction and motivation in competencies and important contributions in terms of social impact. However, this methodology is relatively new, and can still offer room for improvement in the design of more effective learning experiences. Consideration should be given to the management of workspaces in which students can carry out their projects, as well as requesting the support of mentors and subject matter experts in order to provide students with an enriched and enhanced effective learning experience.

\section{Acknowledgments}

We would like to thank the different Faculties of the CEU San Pablo University, as well as all the students, professors and mentors involved in the realization of this activity oriented to the application and study of results by applying the new Design Sprint methodology in Higher Education.

\section{References}

Alaszewski, A. (2006). Using Diaries for Social Research. Sage, Beverly Hills. Retrieved from https://books.google.es/books?hl=en\&lr=\&id=WqyRLumjbKsC\&oi=fnd\&pg=PP8\&ots=vq67cTLUMM \&sig=1gHgdlI2 $\mathrm{wVdepz} \_$SjcgV7LmDjgg\&redir_esc $=\mathrm{y} \# \mathrm{v}=$ onepage \&q\&f$=$ false

Altman, H. (2018). Gestión Ágil de Proyectos. Amazon Distribution, GmbH, Leipzig. Alemania. Retrieved from https://www.amazon.es/AGIL-Gestion-A\%CC\%81 gil-Proyectos-Kanban/dp/1726883205

Arrieta, A., \& Montes, V. D. (2011). Alfabetización digital: uso de las TIC más allá de una formación instrumental y una buena infraestructura. Revista Colombiana de Ciencia Animal, 3(1), 180-197. https://doi.org/10.24188/recia.v3.n1.2011.360

Barroso Osuna, J. y otros. (2012). La formación del profesorado en TIC, visión enfocada en la enseñanza y el 
aprendizaje. $\quad$ Global, $48, \quad 48-55 . \quad$ Retrieved from https://revista.global/la-formacion-del-profesorado-en-tic-vision-enfocada-en-la-ensenanza-y-el-apren dizaje/

Baulina, N. S., Starikowa, A. V., Glukhikh, V. V., Shishlov, O. F., \& Kovalev, A. A. (2018). Modeling of properties of the oriented strand board in STATGRAPHICS. CEUR Workshop. Retrieved from https://ceur-ws.org/Vol-2131/paper8.pdf

Bonilla-del-Río, M., \& Aguaded, I. (2018). La escuela en la era digital: smartphones, apps y programación en Educación Superior y su repercusión en la competencia mediática del alumnado. Píxel-Bit, 53, 151-163. https://doi.org/10.12795/pixelbit.2018.i53.10

Cabero Almenara, J. (2014). Formación del profesorado universitario en TIC. Aplicación del método Delphi para la selección de los contenidos formativos. Educación XX1, 17(1), 1-32. https://doi.org/10.5944/educxx1.17.1.10707

Centeno Moreno, G., \& Cubo Delgado, S. (2013). Evaluación de la competencia digital y las actitudes hacia las TIC del alumnado universitario. Revista de Investigación Educativa, 31(2), 517-536. https://doi.org/10.6018/rie.31.2.169271

Cohn, M. (2004). User Stories Applied: For Agile Software Development. Addison-Wesley Professional, Boston. Retrieved from https://books.google.es/books?id=SvIwuX4SVigC\&lpg=PP15\&ots=VrRea6wSSL\&lr\&pg=PP15\#v=onep age\&q\&f=false

Colás, P., González, T., \& De Pablos, J. (2013). Juventud y redes sociales: Motivaciones y usos preferentes. Comunicar, 40, 15-23. https://doi.org/10.3916/C40-2013-02-01

Da Silva, T. S., Martin, A., \& Maurer, F. (2011). User-centered design and agile methods: a systematic review. In 2011 Agile Conference, pp. 77-86. https://doi.org/10.1109/AGILE.2011.24

Da Silva, T. S., Silveira, M. S., \& Maurer, F. (2012). User experience design and Agile development: from theory to practice. J. Softw. Eng. Appl., 5(10), 743-751. https://doi.org/10.4236/jsea.2012.510087

Direkova, N. (2015). Design sprint methods - Playbook for start up and designers. Retrieved from https://link.springer.com/chapter/10.1007/978-3-319-39294-3_5

Emelyanova, N., \& Voronina, E. (2014). Introducing a learning management system at a russian university: students' and teachers' perceptions. The International Review Research in Open and Distance Learning, 15(1), 272-289. https://doi.org/10.19173/irrodl.v15i1.1701

Feyen, J. (2020). Logrará la COVID-19 acelerar la transición del aprendizaje pasivo a la educación activa? Maskana, 11(1), 1-4. https://doi.org/10.18537/mskn.11.01.00

Fidalgo, A., Sein-Echaluce, M. L., \& García, F. J. (2017). Aprendizaje Basado en Retos en una asignatura universitaria. Revista Iberoamericana de Informática Educativa, 25, 1-8. Retrieved from https://gredos.usal.es/bitstream/handle/10366/133284/GRIAL_Aprendizajeretos.pdf?sequence=1

Fox, D., Sillito, J., \& Maurer, F. (2008). Agile methods and user-centered design: how these two methodologies are being successfully integrated in industry. Agile 2008 Conference, 63-72. IEEE. https://doi.org/10.1109/Agile.2008.78

Freire, J. (2009). Monográfico cultura digital y prácticas creativas en educación. RUSC, Revista de Universidad y Sociedad del Conocimiento, 6(1). http://doi.org/10.7238/rusc.v6i1.23

Garrote Rojas, D., Jiménez-Fernández, S., \& Serna Rodríguez, R. (2018). Gestión del tiempo y uso de las TIC en estudiantes universitarios. Píxel-Bit, 53, 109-121. https://doi.org/10.12795/pixelbit.2018.i53.07

Glass, G. V., \& Stanley, J. C. (1974). Métodos Estadísticos Aplicados a las Ciencias Sociales. Madrid: Prentice-Hall. Retrieved from https://virtual.urbe.edu/librotexto/310_GLA_1/indice.pdf

Harnad, S. (1991). Post-Guttemberg Galaxy: The Fourth Revolution in the Means of production of Knowledge. The Public-Access Computer System Review, 2(1), 39-53. Retrieved from https://eprints.soton.ac.uk/253376/1/harnad91.postgutenberg.html

IBM. IBM Design Thinking. Retrieved from http://www.ibm.com/design/thinking/

Iivari, J. (2015). Distinguishing and contrasting two strategies for design science research. Eur. J. Inf. Syst, 24(1), 107-115. https://doi.org/10.1057/ejis.2013.35 
Jou, M., Hung, C. K., \& Lai, S. H. (2010). Application of Challenge Based Leraning Approaches in Robotics Education. International Journal of Technology and Engineering Education, 7(2), 1-42. Retrieved from https://ijtee.org/ijtee/system/db/pdf/72.pdf

Jou, M., Hung, C. K., \& Lai, S. H. (2010). Application of Challenge Based Leraning Approaches in Robotics Education. International Journal of Technology and Engineering Education, 7(2), 1-42. Retrieved from https://ijtee.org/ijtee/system/db/pdf/72.pdf

Judd, C. H., McClelland, G. H., \& Ryan, C. S. (2009). Data Analysis: A Model Comparison Approach. (2nd ed.) Routledge.

New York.

EE.UU. https://books.google.es/books?id=APusAgAAQBAJ\&lpg=PP1\&ots=BcLSuJ-b95\&lr\&pg=PP1\#v=onepage $\& \mathrm{q} \& \mathrm{f}=$ false

Keijzer-Broers, W., \& De Reuver, M. (2015). Developing a health and wellbeing platform in a living lab setting: an action design research study. Tenth International Conference on Design Science Research in Information Systems and Technology. Dublin. Retrieved from https://link.springer.com/chapter/10.1007/978-3-319-39294-3_5

Keijzer-Broers, W. J. W., de Reuver, G. A., \& Guldemond, N. A. (2015). Designing a multi-sided health and wellbeing platform: results of a first design cycle. In Bodine, C., Helal, S., Gu, T., \& Mokhtari, M. (Eds.), ICOST 2014. LNCS, 8456, 3-12. Springer, Heidelberg. https://doi.org/10.1007/978-3-319-14424-5_1

Keppel, G. (1991). Design and analysis: A researcher's handbook (3rd ed.). Prentice-Hall, Inc. Retrieved from https://psycnet.apa.org/record/1991-98751-000

Kim, J., Kwon, Y., \& Cho, D. (2011). Investigating factors that influence social presence and learning outcomes in distance higher education. Computers \& Education, 57(2), 1512-1520. https://doi.org/10.1016/j.compedu.2011.02.005

Knapp, J., Zeratsky, J., \& Kowitz, B. (2016). Sprint: how to Solve Big Problems and Test New Ideas in Just Five Days. Google $\quad$ Ventures. $\quad$ Retrieved from https://books.google.es/books?id=QupUDgAAQBAJ\&lpg=PP1\&pg=PP1\#v=onepage \&q\&f=false

Lledó, P. (2012). Lean Project Management. Primera edición. Tradfford Publishing. EE.UU. Retrieved from https://books.google.es/books?id=2qQVsB0piV0C\&lpg=PT11\&ots=Qtw1GisjPe\&dq=Gesti\%C3\%B3n\%20 $\% \mathrm{C} 3 \%$ A4gil $\% 20 \mathrm{de} \% 20$ Proyectos\&lr\&pg=PA1\#v=onepage\&q=Gesti $\% \mathrm{C3} \% \mathrm{~B} 3 \mathrm{n} \% 20 \% \mathrm{C} 3 \% \mathrm{~A} 4 \mathrm{gil} \% 20 \mathrm{de} \%$ 20Proyectos\& $\mathrm{f}=$ false

Long, F. (2009). Real or imaginary: The effectiveness of using personas in product design. Proceedings of the Irish Ergonomics Society Annual Conference, pp. 1-10. Retrieved from https://media.loft.io.s3.amazonaws.com/attachments/Long\%20(2009)\%20Real\%20or\%20Imaginary.pdf

Markus, M. L., Majchrzak, A., \& Gasser, L. (2002). A design theory for systems that support emergent knowledge processes. MIS Q., 26(3), 179-212. Retrieved from https://www.jstor.org/stable/4132330

Maroto, A. (2007). El uso de las nuevas tecnologías en el profesorado universitario. Pixel-Bit, 39, $211-223$. Retrieved from https://recyt.fecyt.es/index.php/pixel/article/view/61303

Morales, J. (2020). Oportunidad o Crisis Educativa: Reflexiones desde la Psicología para Enfrentar los Procesos de Enseñanza-Aprendizaje en Tiempos de Covid-19. Revista Internacional de Educación para la Justicia Social, 9(3). Retrieved from https://revistas.uam.es/riejs/article/view/12228

Mullarkey, M. T., \& Hevner, A. R. (2015). Entering Action Design Research. In Donnellan, B., Helfert, M., Kenneally, J., VanderMeer, D., Rothenberger, M., \& Winter, R. (Eds.). DESRIST 2015, LNCS, 9073, 121-134. Heringer, Heidelberg. $\quad$ Retrieved from https://link.springer.com/chapter/10.1007/978-3-319-18714-3_8

Pérez-Escoda, A., Castro-Zubizarreta, A., \& Fandos-Igado, M. (2016). La competencia digital de la Generación $\mathrm{Z}$ : claves para su introducción curricular en la Educación Primaria. Comunicar, 24(49). https://doi.org/10.3916/C49-2016-07

Polhemus, N. W. (2006). How to: Analyze a repeated measures experiment using STATGRAPHICS Centurion. Statpoint, Inc. Retrieved from https://www.statvision.com/How\%20To\%20Analyze\%20a\%20Repeated\%20Measures\%20Experiment.pdf

Poot-Delgado, C. A. (2013). Retos del Aprendizaje Basado en Problemas. Enseñanza e Investigación en Psicología, 18(2), 307-314. Retrieved from https:/www.redalyc.org/pdf/292/29228336007.pdf 
Preece, J., Sharp, H., \& Rogers, Y. (2015). Interaction Design - Beyond Human-Computer Interaction. Wiley, New York. $\quad$ Retrieved from https://books.google.es/books?id=n0h9CAAAQBAJ\&lpg=PR10\&ots=25wPB3hDhV\&lr\&pg=PR1\#v=on epage \&q\&f=false

Prieto, E. (2008). El papel del profesorado en la actualidad. Su función docente y social. Foro de educación, 6(10), 325-345. Retrieved from https://dialnet.unirioja.es/servlet/articulo?codigo=2907073

Rekalde, I., \& García, J. (2015). El aprendizaje basado en Proyectos: un constante desafío. Innovación Educativa, 25, 219-234. Retrieved from https://revistas.usc.gal/index.php/ie/article/view/2304

Salinas, J. (2002). Modelos flexibles como respuesta de las universidades a la sociedad de la información. Acción Pedagógica, 11(1), 4-13. Retrieved from https://dialnet.unirioja.es/servlet/articulo?codigo=2973024

Salinas, J. (2004). Innovación docente y uso de las TIC en la enseñanza universitaria. Revista de Universidad y Sociedad del Conocimiento, 1(1), 1-16. https://doi.org/10.7238/rusc.v1i1.228

Sanglier, G., López, E. J., Cesteros, S., \& González, R. A. (2021). Didactics and Sustainable. A different paradigma in the search for other ideas: Dynamic Architecture. Contemporary Engineering Science, 14(1), 11-22. https://doi.org/10.12988/ces.2021.91619

Sanglier, G., Martínez, C. B., Serrano, I., \& Zuíl, J. C. (2020). Higher Education in the Face of the Push of the New Technology. Virtual, Augmented and Mixed Reality in the Teaching Environment. Contemporary Engineering Science. https://doi.org/10.12988/ces.2020.91601

Schwaber, K. (2004). Agile Project Management with Scrum. Microsoft Press, USA. Retrieved from https://books.google.es/books?id=6pZCAwAAQBAJ\&lpg=PT9\&ots=kcoTSTenlS\&lr\&pg=PP1\#v=onepa ge\&q\&f=false

Sein, M., Henfridsson, O., Purao, S., Rossi, M., \& Lindgren, R. (2011). Action design research. MIS Q., 35(1), 37-56. https://doi.org/10.2307/23043488

Sy, D. (2007). Adapting usability investigations for agile user-centered design. J. Usability Stud., 2(3), 112-132. Retrieved from https://uxpajournal.org/wp-content/uploads/pdf/JUS_Sy_May2007.pdf

Valerio, C., \& Paredes, J. (2008). Evaluación del uso y manejo de las tecnologías de información y comunicación en los docentes universitarios. Un caso mexicano. Revista Latinoamericana de Tecnología Educativa, 7(1), 13-32. Retrieved from https://relatec.unex.es/article/view/391

Venable, J. (2006). The role of theory and theorising in design science research. DESRIST, 1-18. Retrieved from https://citeseerx.ist.psu.edu/viewdoc/download?doi=10.1.1.110.2475\&rep=rep1\&type=pdf

Vera, J. A., Torres, L. E., \& Martínez, E. E. (2014). Evaluación de competencias básicas en TIC en docentes de educación superior. Píxel-Bit, 44, 143-155. https://doi.org/10.12795/pixelbit.2014.i44.10

Verschuren, P., \& Hartog, R. (2005). Evaluation in design-oriented research. Qual. Quant., 39(6), 733-762. https://doi.org/10.1007/s11135-005-3150-6

Villafuerte, J., Bello, J., Cevallos, Y., \& Bermello J. (2020). Rol de los docentes ante la crisis del Covid-19, una mirada desde el enfoque humano. REFCalE: Revista Electrónica Formación y Calidad Educativa, 8(1), 134-150. Retrieved from https://refcale.uleam.edu.ec/index.php/refcale/article/view/3214

\section{Copyrights}

Copyright for this article is retained by the author(s), with first publication rights granted to the journal.

This is an open-access article distributed under the terms and conditions of the Creative Commons Attribution license (http://creativecommons.org/licenses/by/4.0/). 